\title{
Factors Affecting Device Adherence of Patients with Obstructive Sleep Apnea Syndrome in the COVID-19 Pandemic and Normalization Process
}

\section{COVID-19 Pandemi ve Normalizasyon Sürecinde Obstrüktif Uyku Apne Sendromlu Hastaların Cihaz Uyumunu Etkileyen Faktörler}

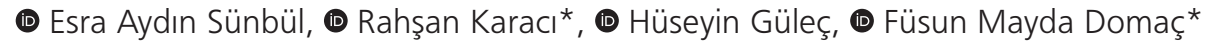 \\ University of Health Sciences Turkey, Erenköy Mental Health and Neurological Diseases Training and Research Hospital, Clinic of Psychiatry, Istanbul, Turkey \\ *University of Health Sciences Turkey, Erenköy Mental Health and Neurological Diseases Training and Research Hospital, Clinic of Neurology, Istanbul, Turkey
}

\begin{abstract}
Objective: Obstructive sleep apnea syndrome (OSAS) is a common sleep-related breathing disorder. Continuous positive airway pressure (CPAP) therapy is the most effective OSAS treatment; however, adherence to CPAP therapy is problematic with psychological symptoms and other sleep disorders. We investigated whether a difference existed between device compatibility of patients with OSAS who applied to the sleep outpatient clinic during the Coronavirus disease-2019 (COVID-19) pandemic and normalization process and those who applied during preepidemic period.

Materials and Methods: This study was a retrospective study. Patients with OSAS who applied to the sleep disorders center for device control between March 27, 2020 and July 1, 2020 and who used a device for at least one year were included. CPAP adherence time during this period and the same period in 2019 were compared.

Results: This study included 190 patients. Regarding the usage times of the device, the average usage time before the pandemic was $5.3 \pm 0.6$ hours, whereas after the pandemic, it was $4.5 \pm 0.9$ hours. The device usage time of 54 patients was over four hours before the pandemic; however, it decreased to under four hours after the pandemic. Regarding insomnia, anxiety, and circadian rhythm disorder, there was a significant difference between patients with adequate device use times and patients with inadequate device use times.

Conclusion: During the COVID-19 pandemic period, additional sleep disorders, such as insomnia, circadian rhythm disorder, nightmare disorder, and psychological problems, like anxiety symptoms, were expeienced by patients with OSAS. These added sleep and psychological problems affected the device compatibility of patients with OSAS. Knowing the problems that may arise during the COVID-19 pandemic process and conducting studies on these issues will help patients with OSAS, a risky group, improve device compliance.
\end{abstract}

Keywords: COVID-19, CPAP adherence, obstructive sleep apnea, pandemic
Öz

Amaç: Obstrüktif uyku apne sendromu (OUAS), yaygın görülen uyku ile ilişkili bir solunum bozukluğudur. Sürekli pozitif hava yolu basıncı (CPAP) tedavisi, OUAS'nin en etkili tedavisi olmakla birlikte, psikolojik semptomlar ve diğer uyku bozuklukları varlığında CPAP tedavisine uyumda güçlükler yaşanabilmektedir. Biz de çalışmamızda, Koronavirüs hastalığı-2019 (COVID-19) pandemisi ve normalleşme sürecinde OUAS hastalarının cihaz uyumluluğunda salgın öncesi döneme göre farklıık olup olmadığını araştırmayı amaçladık.

Gereç ve Yöntem: Araştırmamız retrospektif olgu-kontrol çalışması olup çalışmaya 27.03.2020-01.07.2020 tarihleri arasında uyku polikliniğine cihaz kontrolü için başvuran ve en az 1 aylık cihaz kullanım süresi olan 190 OUAS hastası dahil edilmiştir. COVID-19 pandemi-normalleşme süreci ile pandemi öncesindeki ortalama CPAP kullanım süreleri karşılaştırılmıştır.

Bulgular: Cihaz kullanım sürelerine bakıldığında pandemi öncesi

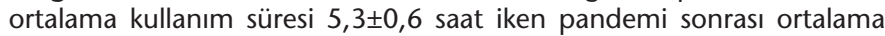
cihaz kullanım süresi 4,5 50,9 saatti. Elli dört hastanın cihaz kullanım süresi pandemi öncesi 4 saatin üzerindeyken, pandemi sonrası 4 saatin altına düşmüştü. Yeterli cihaz kullanım süresi olan hastalarla yetersiz cihaz kullanım süresi olan hastalar karşılaştııılığında, aralarında insomni, anksiyete ve sirkadyen ritim bozukluğu açısından anlamlı fark olduğu görüldü.

Sonuç: OUAS hastalarına COVID-19 pandemi döneminde insomni, sirkadyen ritim bozukluğu, kabus bozukluğu gibi uyku bozuklukları eklenmiştir. Eklenen bu uyku bozukluklarının, OUAS hastalarının cihaz uyumunu etkilediği gözlenmiştir.

Anahtar Kelimeler: COVID-19, CPAP uyumu, obstrüktif uyku apne, pandemi

Address for Correspondence/Yazışma Adresi: Esra Aydın Sünbül MD, University of Health Sciences Turkey, Erenköy Mental Health and Neurological Diseases Training and Research Hospital, Clinic of Psychiatry, İstanbul, Turkey Phone: +90 5066871125 E-mail: dresraaydin@yahoo.com ORCID-ID: orcid.org/0000-0003-1864-9345 Received/Geliş Tarihi: 04.04.2021 Accepted/Kabul Tarihi: 29.06.2021

${ }^{\circ}$ Copyright 2022 by Turkish Sleep Medicine Society / Journal of Turkish Sleep Medicine published by Galenos Publishing House. 


\section{Introduction}

Coronavirus disease-2019 (COVID-19) pandemic is a virus outbreak that occurred on December 1, 2019, in China. The transmission rate of the virus increased in mid-January 2020 and spread to the whole world. Pandemic affects both physical health and human psychology, also it affects the mental health and wellbeing of the uninfected community $(1,2)$. Studies previously conducted during severe acute respiratory syndrome (SARS) infection have shown that stress, anxiety, and depressive complaints increased in the general population during the infection process (3). During the SARS-CoV-19 pandemic, it has been shown that daytime functionality and nighttime sleep are affected due to medical or social isolation, adding working remotely at home, distance education at home, decreased social communication, and health-related concerns (4). This situation causes psychiatric illnesses and sleep disorders or the advance of previous disorders.

Obstructive sleep apnea syndrome (OSAS) is the most common sleep-related breathing disorder. This disease is often accompanied by hypertension, diabetes, cardiovascular disease, and obesity. Obstructive apneic events; oxidative stress triggers sympathetic activation and inflammation, leading to the onset and progression of cardiac, vascular, metabolic, and cerebrovascular diseases $(5,6)$. Intermittent hypoxia increases hypoxemic stress and causes reactive oxygen molecules to be released (7). In studies conducted with patients with OSAS, pro-inflammatory cytokines such as TNF-alpha and interleukin (IL)-6, IL-8, high levels of nuclear factor kappa B showed that inflammation plays a role in OSAS (8).

The most effective treatment of OSAS is continuous positive airway pressure (CPAP) therapy. With CPAP treatment, symptoms such as snoring, excessive sleepiness, morning headache, concentration and attention deficit, memory problems, and mood changes improve. There is a decrease in insulin resistance, stroke, hypertension, and cardiovascular disease risks (9). Also, it provides a decrease in traffic accidents and an increase in work efficiency (9). As the rate of CPAP usage, which has such significant effects, increases, its effectiveness increases; it is intended to use more than 4 hours a night $(10,11)$. However, less than half of those use CPAP within the recommended period (12). Compliance with device therapy can be problematic, especially in some groups. It was observed that CPAP compliance decreased in the presence of an additional psychiatric disorder or other sleep disorder (13). Studies in patients with post-traumatic stress disorder (PTSD) have shown the relationship between anxiety and depression and low device compliance $(14,15)$. Insomnia, sleep divisions, and recurrent arousals can affect CPAP compliance (16). Poor sleep quality, nightmares, mask-related problems, claustrophobia are other factors associated with low CPAP compliance. Therefore, psychiatric disorders and sleep disorders arising in the COVID19 pandemic process are thought to affect CPAP compliance. Stopping PAP titration device usage during a pandemic may cause both psychological and physical changes during social isolation. However, it is very important to continue to use
PAP titration effectively, especially in people with an increased workload, who continue driving a car and working with the device during a pandemic (17).

In our study, we aimed to investigate whether there is a difference in device compatibility of the OSAS patients who applied to the sleep outpatient clinic during the COVID-19 pandemic and normalization process compared to the preepidemic period.

\section{Materials and Methods}

This retrospective study was performed at the Sleep Disorders Center of the University of Health Sciences Turkey, Erenköy Mental and Neurological Diseases Training and Research Hospital. All study procedures were approved by the Local Ethics Committee and are compliant with the Declaration of Helsinki (no: 25, date: 06.07.2020). Because the study was retrospective, informed consent was not obtained from patients, but patient identification information was hidden.

In sleep disorders outpatient clinic, all of the admitted patients with the complaints of sleep-related breathing problems fill out Berlin questionnaire (18), the patient health questionnaire-9 (PHQ-9), the general anxiety disorder-7, and PHQ-15 scale (19). These scales are well- established instruments for screening for symptoms of depression, generalized anxiety, and somatization respectively, scores of which 5-9: Mild, 10-14: Moderate, $\geq 15$ : Severe anxiety symptoms. In our study, we accepted a score of five and above as the presence of related symptoms. If OSAS is suspected according to answers of Berlin questionnaire, the patients have a full night polysomnography (PSG). The patient who has $>5$ apnea-hypopnea index (AHI) is diagnosed with OSAS. When $\mathrm{AHI}>15$ or AHI between 5-15 with high Epworth score or additional systemic disease like hypertension, diabetes mellitus etc. or a history of stroke, the patient has a second full night PSG with positive airway pressure (PAP) titration device to determine the appropriate device and pressure. Then the patients are followed at our outpatient clinic for clinical recovery and device adherence periodically.

In this study, we have included the patients who were diagnosed as OSAS according to PSG applied at our sleep disorders center and under treatment with PAP device before pandemic for at least 1 year. We have compared the device adherence of the patients before COVID-19 pandemia and between the date of the first COVID-19 patient diagnosed at 27.03.2020 and the end of the curfew date at 01.07.2020. Patients with OSAS who never used a device or used irregularly or had a device use period of less than 1 year were excluded. Medical records included patients' age, gender, PSG results, psychiatric symptoms, other sleep disorders, device usage times. CPAP adherence during the same period in the year of 2019 was documented also.

\section{Statistical Analysis}

Statistical analysis was performed using SPSS for Windows (version 20.0; SPSS Inc, Chicago, Illinois). The KolmogorovSmirnov test was used to determine whether the data were normally distributed. Continuous data were expressed as mean 
\pm standard deviation or median (interquartile range) while categorical data were presented as the number of patients and percentages. Student t-test or Mann-Whitney $U$ test was used to compare parametric and non-parametric continuous variables, respectively. Pearson chi-square and Fisher's Exact tests were used for statistical evaluation of the categorical variables. Logistic regression analysis was performed to determinate the predictors of device adherence. A p-value $<0.05$ was considered statistically significant.

\section{Results}

A total of 190 patients were included in our study. One hundred-fifty five of the patients were male (81.6\%) and 35 were female (18.4\%). The average age of the patients was 50.2 \pm 11.8 . According to the PSG results, mean AHI values were $44.3 \pm 26.4$. Considering the usage times of the device, the average usage time before the pandemic was $5.3 \pm 0.6$ hours, while the average device usage time after the pandemic was $4.5 \pm 0.9$ hours. While the device usage time of 54 patients was over 4 hours before the pandemic, it was below 4 hours after the pandemic. Patients were divided into two groups such as patients with inadequate usage time (whose device usage time was $<4$ hours) and patients with adequate usage time (whose device usage time $\geq 4$ hours). There was no difference in age and gender between the groups. When patients with adequate device usage time and patients with inadequate device usage time were compared, there was a significant difference between them in terms of age, gender, and mask problems. Insomnia and circadian rhythm disturbances were more common in the group with insufficient device compatibility (Table 1).

When examined in terms of psychiatric problems, anxiety and somatic symptoms were significantly higher in the group with insufficient device compatibility (Table 2). Multivariate logistic regression analysis was performed to determinate the predictors of device adherence. Presence of insomnia, circadian rhythm disturbances, and anxiety symptoms were independent predictors of device adherence (Table 3).

\section{Discussion}

In large cohort studies reported from China and Italy, people with COVID-19 infection had high comorbidity of hypertension, diabetes, and heart disease. These characteristics are often

\begin{tabular}{|l|l|l|l|}
\hline \multicolumn{1}{|l|}{$\begin{array}{l}\text { Table 1. Comparison of the socio-demographic and clinical } \\
\text { characteristics between groups }\end{array}$} & $\begin{array}{l}\text { Inadequate } \\
\text { device } \\
\text { adherence } \\
(\mathbf{n}=54)\end{array}$ & $\begin{array}{l}\text { Adequate } \\
\text { device } \\
\text { adherence } \\
(\mathbf{n}=136)\end{array}$ & $\mathbf{p}$ \\
\hline Age (years) & $50.7 \pm 11.2$ & $50.0 \pm 12.1$ & 0.730 \\
\hline Gender (male) & $47(87)$ & $108(79.4)$ & 0.300 \\
\hline Mask problem & $3(5.6)$ & $3(2.2)$ & 0.354 \\
\hline Nightmare disorder & $3(5.6)$ & $1(0.7)$ & 0.070 \\
\hline Insomnia & $14(25.9)$ & $2(1.5)$ & $<0.001$ \\
\hline Circadian rhythm disorder & $11(20.4)$ & $6(4.4)$ & $\mathbf{0 . 0 0 1}$ \\
\hline
\end{tabular}

found in OSAS also. Approximately one-fourth of patients who have had COVID-19 pneumonia and developed intensive care need have a history of OSAS (20). Hypoxemia during sleep in both OSAS and obesity hypoventilation syndrome increases hypoxemia in COVID-19 pneumonia. It is thought that hypoxemia is deeper and cytokine storm develops in OSAS patients, especially accompanied by obesity (7). Furthermore, there are as yet unexplored potential mechanistic links between an imbalance of the angiotensin II receptor and angiotensin II converting enzyme (ACE2) and severe COVID-19 infections, which may also apply in sleep related breathing disorder (21). In OSAS patients, the cytokine storm may worsen COVID-19 pneumonia; acute respiratory distress syndrome (ARDS) and multi-organ failure may develop. ARDS is high in OSAS patients accompanied by obesity (22).

CPAP is an effective treatment of OSAS. Patients who use CPAP for more than 4 hours a night, more than $70 \%$ of the days using CPAP, are considered compatible with the treatment (23). However, half of the patients experience device compatibility problems (24). Many factors affect device compatibilities, such as mask problems, the presence of other sleep disorders, and psychological state. It is thought that many situations such as measures taken throughout the country during the COVID-19 pandemic, isolation, quarantine, digital work environments may have directly or indirectly affected device compatibility. In previous studies, low CPAP compliance has been shown in PTSD and additional sleep disorders (25). Different results were found in two studies on device compatibility during the COVID19 pandemic process. Attias and colleagues evaluated device compatibility in the first month of the COVID-19 pandemic of 7.485 patients with OSAS; the usage time increased from 386 minutes before the pandemic to 401 minutes. They attributed this to conditions such as the fear of hospitalization, staying at home, not being exposed to air pollution, and reduced work stress due to cardiovascular risk factors in most OSAS patients (26). However, Batool-Anwar et al. (27) found no differences in hours of PAP use or self-

\begin{tabular}{|l|l|l|l|}
\hline \multicolumn{1}{|c|}{ Table 2. Comparison of the psychiatric symptoms between groups } \\
\hline & $\begin{array}{l}\text { Inadequate } \\
\text { device } \\
\text { adherence } \\
(\mathrm{n}=54)\end{array}$ & $\begin{array}{l}\text { Adequate } \\
\text { device } \\
\text { adherence } \\
(\mathrm{n}=136)\end{array}$ & $\mathrm{p}$ \\
\hline Depressive symptoms & $1(1.9)$ & 0 & 0.284 \\
\hline Anxiety symptoms & $12(22.6)$ & $6(4.4)$ & $<0.001$ \\
\hline Somatic symptoms & $3(5.6)$ & $1(0.7)$ & 0.070 \\
\hline
\end{tabular}

Table 3. Multivariate logistic regression analysis to determinate predictors of device adherence

\begin{tabular}{|l|l|l|l|}
\hline & $\begin{array}{l}\text { Odds } \\
\text { ratio }\end{array}$ & $\begin{array}{l}\mathbf{9 5 \%} \\
\text { confidence } \\
\text { interval }\end{array}$ & $\mathbf{p}$ \\
\hline Insomnia & 23.055 & $4.842-109.742$ & $<\mathbf{0 . 0 0 1}$ \\
\hline Circadian rhythm disorder & 4.037 & $1.221-13.349$ & $\mathbf{0 . 0 2 2}$ \\
\hline Anxiety symptoms & 4.963 & $1.575-15.644$ & $\mathbf{0 . 0 0 6}$ \\
\hline
\end{tabular}


reported sleep duration between before and after COVID19 pandemic. They found that there was an increase in the number of patients with insomnia after the lockdown (27). In our study, the average duration of use, which was $5.3 \pm 0.6$ hours before the COVID-19 pandemic, decreased to $4.5 \pm 0.9$ hours after the pandemic.

Researchers in China investigated the psychological effects of the general population in the first phase of the COVID-19 outbreak. They found that $53.8 \%$ of respondents rated the psychological impact of the outbreak as moderate or severe, $16.5 \%$ reported moderate to severe depressive symptoms, and $28.8 \%$ reported moderate to severe anxiety symptoms (28). In our study, it was observed that depressive symptoms, anxiety symptoms, and somatic complaints were added in the COVID19 pandemic process in OSAS patients. One study examined the relationship between personal social capital scale-16 and sleep quality in individuals who isolated themselves during the COVID-19 outbreak (1). It has been shown that anxiety is associated with stress and decreased sleep quality, and the presence of anxiety and stress reduces the positive effects of social capital on sleep quality. In a study conducted on 1.250 healthcare workers in China, $50.4 \%$ of the participants were found to have depression, $44.6 \%$ anxiety, and $34.0 \%$ insomnia (29). In our study, new insomnia cases were detected during the COVID-19 epidemic period.

\section{Conclusion}

In OSAS patients, sleep disorders such as insomnia, circadian rhythm disorder, nightmare disorder, depressive symptoms, and anxiety symptoms were observed during the COVID-19 pandemic period. These added complaints affected the device compatibility of OSAS patients. Being aware of the problems that may arise during the COVID-19 pandemic process and conducting studies on these issues will help the device compliance of patients with OSAS, a risky group.

\section{Ethics}

Ethics Committee Approval: This retrospective study was performed at the Sleep Disorders Center of the University of Health Sciences Turkey, Erenköy Mental and Neurological Diseases Training and Research Hospital. All study procedures were approved by the Local Ethics Committee and are compliant with the Declaration of Helsinki (no: 25, date: 06.07.2020).

Informed Consent: Informed consent was not obtained from patients, but patient identification information was hidden.

Peer-review: Externally and internally peer-reviewed.

\section{Authorship Contributions}

Concept: E.A.S., Design: F.M.D., Data Collection or Processing: R.K., Analysis or Interpretation: H.G., Literature Search: F.M.D., Writing: E.A.S.

Conflict of Interest: No conflict of interest was declared by the authors.

Financial Disclosure: This research did not receive any specific grant from funding agencies in the public, commercial, or notfor-profit sectors.

\section{References}

1. Xiao H, Zhang Y, Kong D, Li S, Yang N. Social Capital and sleep quality in individuals who self-isolated for 14 days during the coronavirus disease 2019 (COVID-19) outbreak in January 2020 in China. Med Sci Monit 2020;26:e923921.

2. Xue Z, Lin L, Zhang S, Gong J, Liu J, Lu J. Sleep problems and medical isolation during the SARS-CoV-2 outbreak. Sleep Med 2020;70:112-5.

3. Wu KK, Chan SK, Ma TM. Posttraumatic stress, anxiety, and depression in survivors of severe acute respiratory syndrome (SARS). J Trauma Stress 2005;18:39-42.

4. Altena E, Baglioni C, Espie CA, Ellis J, Gavriloff D, Holzinger B, Schlarb A, Frase L, Jernelöv S, Riemann D. Dealing with sleep problems during home confinement due to the COVID-19 outbreak: Practical recommendations from a task force of the European CBT-I Academy. J Sleep Res 2020;29:e13052.

5. Lavie L. Obstructive sleep apnoea syndrome--an oxidative stress disorder. Sleep Med Rev 2003;7:35-51.

6. Somers VK, White DP, Amin R, Abraham WT, Costa F, Culebras A, Daniels S, Floras JS, Hunt CE, Olson LJ, Pickering TG, Russell R, Woo M, Young T; American Heart Association Council for High Blood Pressure Research Professional Education Committee, Council on Clinical Cardiology; American Heart Association Stroke Council; American Heart Association Council on Cardiovascular Nursing; American College of Cardiology Foundation. Sleep apnea and cardiovascular disease: an American Heart Association/american College Of Cardiology Foundation Scientific Statement from the American Heart Association Council for High Blood Pressure Research Professional Education Committee, Council on Clinical Cardiology, Stroke Council, and Council On Cardiovascular Nursing. In collaboration with the National Heart, Lung, and Blood Institute National Center on Sleep Disorders Research (National Institutes of Health). Circulation 2008;118:1080-111.

7. McSharry D, Malhotra A. Potential influences of obstructive sleep apnea and obesity on COVID-19 severity. J Clin Sleep Med 2020;16:1645.

8. McNicholas WT. Obstructive sleep apnea and inflammation. Prog Cardiovasc Dis 2009;51:392-9.

9. Chaiard J, Weaver TE. Update on Research and Practices in Major Sleep Disorders: Part I. Obstructive Sleep Apnea Syndrome. J Nurs Scholarsh 2019;51:500-8.

10. Weaver TE, Maislin G, Dinges DF, Bloxham T, George CF, Greenberg H, Kader G, Mahowald M, Younger J, Pack Al. Relationship between hours of CPAP use and achieving normal levels of sleepiness and daily functioning. Sleep 2007;30:711-9.

11. Salepci B, Caglayan B, Kiral N, Parmaksiz ET, Comert SS, Sarac G, Fidan A, Gungor GA. CPAP adherence of patients with obstructive sleep apnea. Respir Care 2013;58:1467-73.

12. Weaver TE, Grunstein RR. Adherence to continuous positive airway pressure therapy: the challenge to effective treatment. Proc Am Thorac Soc 2008;5:173-8.

13. Means MK, Ulmer CS, Edinger JD. Ethnic differences in continuous positive airway pressure (CPAP) adherence in veterans with and without psychiatric disorders. Behav Sleep Med 2010;8:260-73.

14. Sateia MJ. Update on sleep and psychiatric disorders. Chest 2009;135:1370-9.

15. Kjelsberg FN, Ruud EA, Stavem K. Predictors of symptoms of anxiety and depression in obstructive sleep apnea. Sleep Med 2005;6:341-6.

16. Krakow B, Melendrez D, Pedersen B, Johnston L, Hollifield M, Germain A, Koss M, Warner TD, Schrader R. Complex insomnia: insomnia and sleep-disordered breathing in a consecutive series of crime victims with nightmares and PTSD. Biol Psychiatry 2001;49:948-53. 
17. Baker JG, Sovani M. Case for continuing community NIV and CPAP during the COVID-19 epidemic. Thorax 2020;75:368. doi: 10.1136/ thoraxjnl-2020-214913

18. Acar HV, Kaya A, Genç F, Erdem M, Ceyhan A, Özgen F, Dikmen B. Can Berlin Questionnaire be used as a screening test for Obstructive Sleep Apnea? JARSS 2013;21:99-105.

19. Yazici Güleç $M$, Güleç $H$, Simşek $G$, Turhan $M$, Aydin Sünbül E. Psychometric properties of the Turkish version of the Patient Health Questionnaire-Somatic, Anxiety, and Depressive Symptoms. Compr Psychiatry 2012;53:623-9.

20. Bhatraju PK, Ghassemieh BJ, Nichols $M$, Kim R, Jerome KR, Nalla AK, Greninger AL, Pipavath $S$, Wurfel MM, Evans $L$, Kritek PA, West TE, Luks A, Gerbino A, Dale CR, Goldman JD, O'Mahony S, Mikacenic C. Covid-19 in Critically III Patients in the Seattle Region-Case Series. N Engl J Med 2020;382:2012-22.

21. Liu PP, Blet A, Smyth D, Li H. The science underlying COVID-19: implications for the cardiovascular system. Circulation 2020;142:68-78.

22. Karnatovskaia LV, Lee AS, Bender SP, Talmor D, Festic E; US Critical Illness and Injury Trials Group: Lung Injury Prevention Study Investigators (USCIITG-LIPS). Obstructive sleep apnea, obesity, and the development of acute respiratory distress syndrome. J Clin Sleep Med 2014;10:657-62.

23. Kribbs NB, Pack Al, Kline LR, Smith PL, Schwartz AR, Schubert NM, Redline S, Henry JN, Getsy JE, Dinges DF. Objective measurement of patterns of nasal CPAP use by patients with obstructive sleep apnea. Am Rev Respir Dis 1993; 147:887-95.
24. Weaver TE, Sawyer AM. Adherence to continuous positive airway pressure treatment for obstructive sleep apnoea: implications for future interventions. Indian J Med Res 2010;131:245-58.

25. Collen JF, Lettieri CJ, Hoffman M. The impact of posttraumatic stress disorder on CPAP adherence in patients with obstructive sleep apnea. J Clin Sleep Med 2012;8:667-72.

26. Attias D, Pepin JL, Pathak A. Impact of COVID-19 lockdown on adherence to continuous positive airway pressure (CPAP) by obstructive sleep apnoea patients. Eur Respir J 2020;56:2001607. doi: 10.1183/13993003.01607-202

27. Batool-Anwar S, Omobomi OS, Quan SF. Impact of the novel coronavirus disease on treatment adherence and sleep duration in patients with obstructive sleep apnea treated with positive airway pressure. J Clin Sleep Med 2020;16:1917-20.

28. Wang C, Pan R, Wan X, Tan Y, Xu L, Ho CS, Ho RC. Immediate psychological responses and associated factors during the initial stage of the 2019 Coronavirus Disease (COVID-19) epidemic among the general population in China. Int I Environ Res Publ Health 2020;17:1729. doi: 10.3390/ijerph17051729

29. Lai J, Ma S, Wang Y, Cai Z, Hu J, Wei N, Wu J, Du H, Chen T, Li R, Tan H, Kang L, Yao L, Huang M, Wang H, Wang G, Liu Z, Hu S. Factors associated with mental health outcomes among health care workers exposed to Coronavirus Disease 2019. JAMA Netw Open 2020;3:e203976. doi: 10.1001/jamanetworkopen.2020.3976 